HORVÁTH LÁSZLÓ

\title{
HYPEREIDÉS: EUXENIPPOS MELLETT POLYEUKTOSSZAL SZEMBEN HAZAÁRULÁS ÜGYÉBEN
}

\author{
A beszéd keltezése*
}

\begin{abstract}
Hypereidés Euxenippos mellett Polyeuktosszal szemben hazaárulás ügyében elmondott védőbeszédét az első kiadó, Churchill Babington Kr. e. 334-re keltezte. Domenico Comparetti azonban hamarosan Kr. e. 330 és 324 közé szorította a keletkezés lehetséges dátumát. Érvelése szerint a szónok csak úgy idézhette Olympiasnak, Alexandros anyjának az athéni néphez írt leveléből a „Molossia az enyém” kifejezést, ha Olympias már valóban a terület ura volt, tehát Kr. e. 331, azaz fivére halála után. A keltezést jó másfél évszázada tényként kezelik, olyannyira, hogy a kiadók több szövegjavítást és értelmezési alternatívát is ehhez az elképzeléshez igazítottak. A tanulmány amellett érvel, hogy a hagyományozott, jól értelmezhető szövegnek megfelelően a beszédet Kr. e. 334/333-ra kell datálni, javításokra nincs szükség, Churchill Babingtonnak igaza volt.
\end{abstract}

Kulcsszavak: Hypereidés, Euxenippos mellett, Babington, Comparetti, keltezés, Olympias, Molossia

Hypereidés törvényszéki szónoklataihoz írt kommentárjában David Whitehead az Euxenippos-beszéd keltezésének kérdését is tárgyalja a beszédhez írt bevezetőben. ${ }^{1}$ Bár az editor princeps, Churchill Babington az Euxenippos-pert, így a beszédet is közvetlenül az óróposi területek Athénhoz csatolását követő időkre datálta (Alexandros uralkodásának első évei: Kr. e. 334 körül), később Comparetti a keltezés kérdésében olyan meggyőzően érvelt, hogy a consensus philologorum végül a Kr. e. 330-324 közötti időszakban rögzült. ${ }^{2}$ Babington a beszédbéli utalásból, ti. a vádló, Polyeuktos politikus ellen még nem indított pert (Euxenippos ugyanis magánember volt), arra következtetett, hogy a beszéd Polyeuktosnak a Démadés elleni, pontosan keltezhetö (Kr. e. 334) pere előtt keletkezett. Comparetti azonban egyfelől kimutatta, hogy a vádló nem azonos azzal a sphéttosi Polyeuktosszal, aki Démadést perelte, másfelől pedig rámutatott arra is, hogy Olympias, Alexandros anyja Kr. e. 331 elött nem írhatta Molossia uralkodójaként a Hypereidéstől idézett levelét, mert akkoriban a fivére, I. Alexandros még élt, és ő volt az uralkodó (terminus post quem). A terminus ante quemet pedig egyértelmüen a vádló szószólójának, Lykurgosnak a halála jelöli ki: Kr. e. 324. Comparetti datálását egyedül Oikonomides kérdőjelezte meg, de érvei sem az ókortörténészeket, sem a filológusokat

* A tanulmány az NKFIH NN 124539 számú pályázat (Társadalmi kontextus a szövegkritika tükrében: Bizáncon innen és túl) támogatásával jött létre.

${ }^{1}$ D. Whitehead: Hyperides. The Forensic Speeches. Oxford 2000. 155 skk.

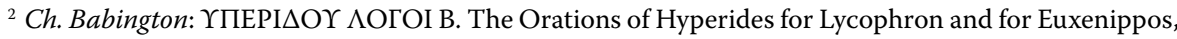
Cambridge 1853. XV. „The date of the speech must certainly be placed in the times of Alexander, probably in the early part of his reign." és D. Comparetti: Il Discorso d' Iperide in Favore d' Euxenippo. Pisa 1861. 44 skk. 
nem érték el, illetve nem győzték meg. ${ }^{3}$ Utóbbiak döntő többsége még arra is hajlandó volt, hogy három szövegjavítást, illetve a klasszikus görögtől idegen jelentést igazítson a mértékadóvá vált keltezéshez. A kivitelben és pontosságban egyaránt rendkívül igényesen hagyományozott szöveg - amolyan datálási Prokrystés-ágyhoz - „nyesegetése” késztetett arra, hogy Hypereidés szövegkiadásának előkészítése során a kérdést újra megvizsgáljam. Számomra ugyanis teljesen egyértelmü, hogy Babingtonnak igaza volt. ${ }^{4}$ Alábbiakban a beszéd létrejöttének és körülményeinek rövid áttekintése után négy egységben sorolom fel az érveket, amelyek az általánosan elfogadott datálást megkérdőjelezik, és a beszédet Kr. e. 333-ra keltezhetik.

\section{A beszéd keletkezésének körülményei, az ügy háttere}

Hypereidés Euxenippos védelmében elmondott beszédét ugyanaz a papirusztekercs tartalmazza, amelynek töredékei a Lykophrón-beszédet is megőrizték. ${ }^{5}$ A két beszéd között számos a hasonlóság. Euxenippost is eisangelia eljárás keretében kísérelték meg elítélni, noha erre valódi jogalap nem volt. A vádlót, akárcsak Lykophrón vádlóját, Aristónt, Lykurgos támogatta, és végül, hogy csak a legfeltűnőbbeket említsem, Hypereidés ugyanazt az érvelési stratégiát alkalmazza a beszéd első részében: a vádlott feltételezett bűne nem tartozik az eisangelia (hazaárulási) perek körébe. Euxenippos bányászatban érdekelt, gazdag athéni polgár volt. Bár nem volt aktív politikus, köztiszteletben álló személy lehetett, aki hajlott korára politikai csatározások kereszttüzébe keveredett. A per előzményei a chairóneiai ütközetig nyúlnak vissza. Philippos, majd fia, Alexandros ugyanis, hogy az egykori szövetségeseket, Athént és Thébait megossza, a hosszú idő óta vitatott határvidéket, Órópost Attikához csatolta. ${ }^{6}$ Órópos Attika északkeleti vagy

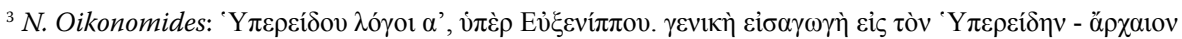

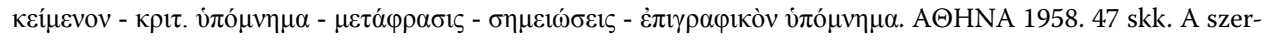
ző ellenérve az volt, hogy Olympias ilyen kijelentést, ti. Molossia az övé, II. Philippos halála után is tehetett, amikor interregnum keletkezett. Másfelöl hangsúlyozza, hogy Olympias (H. Berve: Das Alexanderreich auf prosopographischer Grundlage. München 1926. II. 286 megállapítása szerint) Kr. e. 333-ban ajánlotta fel Hygieiának azt a kupát, amelyet Hypereidés a beszédében említ. Vö. G. Bartolini: Iperide. Rassegna di problemi e di studi (1912-1972). Padova 1976. 70 sk.

${ }^{4}$ Bizonyosan nem véletlen az sem, hogy - bár a Comparetti-féle datálást elfogadják - a kutatók nagy része a beszédet a kijelölt időszakon belül jobbára a kezdő dátumhoz igen közel, Kr. e. 330/329-re datálja. Vö. Whitehead: i. m. (1. jegyz.) 155.

${ }^{5}$ Védőbeszéd Euxenippos mellett Polyeuktosszal szemben hazaárulás ügyében. A beszédről bővebben (fordítással és magyarázatokkal) lásd Horváth L.: Az athéni Hypereidés beszédei és stílusának ókori megítélése. Budapest 2001. 57. skk. Az alábbi áttekintés az idézett közlés javított változata.

${ }^{6}$ Órópos Kleisthenés közigazgatási reformja idején még nem tartozott Attikához, így Athén valamikor Kr. e. 507 és a peloponnésosi háború kezdete között terjesztette ki rá a befolyását. Kr. e. 411-ben a boiótok elfoglalták (Thuk. VIII 60), de Athén Kr. e. 374 körül ismét megszerezte, majd Kr. e. 366-ban megint elveszítette (Xen. Hell. VII 4,1). Az irodalmi utalások alapján Philippos a chairóneiai győzelem után Kr. e. 338-ban ítélte Athénnak (Pausan. I 34,1), de az általánosan elfogadott keltezés mégis Kr. e. 335, Thébai lerombolása. 
Boiótia délkeleti részének tekinthető. ${ }^{7}$ Földrajzi szempontból a terület az Asópos-folyó völgyéhez tartozik, és így a kezdetektől szerves része volt Boiótiának.

Kultikus jelentősége az itt található gyógyító hatású Amphiareion (Amphiaraosszentély) miatt volt, gazdaságpolitikai szempontból azonban különösen azért volt fontos Athén számára, mert itt haladt az Euboia felől érkező és a város számára létfontosságú gabonabehozatal egyik útvonala, amely egyben az Euboia felé vezető hadiutat is jelentette. ${ }^{8}$ Órópos stratégiai jelentőségét a peloponnésosi háború bizonyította, de a terület a mezőgazdasági termelés, elsősorban alighanem az erdőgazdaság szempontjából is fontos volt.

A terület a makedón döntést követően az athéni állam tulajdona lett, és öt egyenlő részre osztották fel, majd azokat kisorsolták a tíz, párokba rendezett phylé között. A szétosztást követően felmerült a gyanú, hogy azt a hegyet, amelyet a Hippothoóntis és az Akamantis phylék kaptak, korábban Amphiaraosnak szentelték, ezért nem lehetett volna a phyléknek átadni. Az ügy tisztázására a népgyülés három polgárt jelölt ki, közöttük Euxenippost, hogy incubatio által fürkésszék ki a gyógyító jós-hérósz, Amphiaraos akaratát, vagyis feküdjenek be, és aludjanak az óróposi Amphiareionban. Euxenippos a várakozásoknak megfelelően álmot látott, és erről jelentést tett a népgyűlésnek. A jelentés pontos tartalma ismeretlen, de valószínủleg a két fent említett phylé kedvére látszott eldőlni a dolog. Ennek ellenére az Aigéis phyléhez tartozó Kydantidai démosbeli Polyeuktos javaslatot terjesztett be, miszerint a terület maradjon meg Amphiaraosnak, a két phylét pedig kárpótolja a többi. A javaslatot elvetették, és Polyeuktost graphé paranomón eljárás keretében huszonöt drachmára bírságolták. A büntetés példátlanul mérsékelt volt, amit magyarázhat az a feltételezés, hogy a kárpótlási javaslatot a tekintélyes politikus, Lykurgos is támogatta. Nem kizárt azonban, hogy a döntés, az enyhe bírság oka az anyagi áldozatot elutasító nyolc phylé „rossz lelkiismerete” volt. Polyeuktos mindenesetre nem adta fel, és Lykurgos segítségével megtámadta Euxenippost, miszerint valakik megvesztegették, hogy a kedvükre „álmodjon”.

A per politikai hátteréről a szakirodalomban különböző magyarázatok olvashatók. Engels - akárcsak Lykophrón esetében - az Euxenippos-pert is a gazdag athéni bányabérlők elleni támadásként értelmezi, amelynek sikeréből Lykurgos anyagi hasznot remélt építkezéseihez. Engels egyik fő bizonyítékát Lewis kutatási eredményei szolgáltatják. Lewis ugyanis a kis-Panathénaia-felirat alapján megállapította, hogy a Kr. e. IV. század közepén Athénban egy-egy ünnep megrendezésére nem volt mindig kellő anyagi fede-

Kr. e. 322-től a demokratikus Athén végső meggyengülésével önállósodott (Diod. XVIII 56,6), majd Kr. e. 312-ben újból Thébaihoz tartozott (Diod. XIX 78,3), Kr. e. 304-től athéni, majd Kr. e. 287-től ismét boiót, Kr. e. 171-től pedig független terület (Polyb. XXXII 11,5).

${ }^{7}$ Valójában minden bizonnyal eretriai eredetű kolóniaként sem boiót, sem athéni identitása nem volt. Lásd A. Wilding: Aspirations and Identities: Proxenia at Oropos during the Fourth to Second Centuries BC. BICS 58/2 (2015) 69, 73. jegyz. a vonatkozó szakirodalom összegzésével.

8 Thuk. VII 28.

${ }^{9}$ A legújabb áttekintés: $R$. Van Hove: A Dream on Trial. The Contest of Oracular Interpretations and Authorities in Hyperides' In Defence of Euxenippus. Mnemosyne 72 (2019) 405 skk. 
zet. ${ }^{10}$ Magam inkább azt feltételezem, hogy elsősorban nem Euxenippos vagyonának megszerzése volt a cél, hanem sokkal inkább az, hogy az állam a két phylétől „bitorolt” terület vissza- vagy megszerzésével Amphiaraos kultuszának anyagi hátterét hosszú távon is biztosítsa.

Lykurgos a Thébaitól megszerzett területet örökös athéni birtokká kívánta tenni, ezért átfogó kultúrpolitikai lépéseket foganatosított. Ennek nemcsak a Kr. e. IV. század közepére datálható (lásd alább 4. pont) építkezés és az ünnepség bevezetése volt a része, hanem mítoszváltozatok létrehozása is. Amphiaraost a szekerével az athéni érdekek szerint alakított mítoszban feltehetően nem Thébai mellett, hanem Óróposban nyelte el a föld. A Kr. e. 330-as évekből ismeretes hasonló kultúrpolitikai erőfeszítésekre Hypereidés Déliakos-beszédének mitológiai háttere is beszédes példa. ${ }^{11}$ Lykurgos és segítői az Amphiareion feletti protektorátussal minden bizonnyal a területet is biztosítani vélték Athén számára. Jóllehet Engelsnek általában igaza lehet, talán nem hangsúlyozza kellőképpen, hogy az Euxenippos-pert megelőzte egy sikertelen kísérlet, amelynek során a vitatott területet egyszerủen az Amphiareion-temenos részévé próbálták nyilváníttatni. Elképzelhető tehát, hogy Lykurgosnak csupán jövedelmet adó területre volt szüksége a forrásokból ismert jelentős építkezések és átalakítások kivitelezésére. Tehát nem feltétlenül a bányabérlők elleni támadás volt a per meghatározó indítéka, Hypereidés csupán szónoki fogásként használta az érvet.

Bár a vádbeszédek nem maradtak ránk, aligha kétséges, hogy a vádlók Euxenippos feltételezett büntettében a kultuszoknak, a közösség megtartó erejének aláásását igyekezték kidomborítani, amely így kimeríthette a hazaárulás minősített esetét. Hypereidés szavaiból arra következtethetünk, hogy Euxenippost a makedónok szekértolójaként és az állami vagyon sikkasztójaként festették le. Ezért kerültek Hypereidés védőbeszédébe a makedónokra, így Olympias cselekedeteire vonatkozó hivatkozások és Euxenippos tettének említése (ti. hagyta, hogy Olympias fogadalmi ajándékot helyezzen el Hygieia athéni szentélyében). A szónok mint szószóló lépett a bírák elé, így a ránk maradt beszéd minden bizonnyal másodbeszéd, azaz deuterologion.

Érvek a Kr. e. 333. évi datálás mellett

1. Comparetti álláspontjával szemben véleményem szerint Olympias nem Molossia „hivatalos" uralkodójaként (tehát Kr. e. 331 után [?]) nehezményezte leveleiben az athéniak Dióné kultuszával kapcsolatos dódónéi jámbor igyekezetét, a kultusz-szobor felékesítését, hanem ottani származása és vallásos kötődése okán. A vonatkozó szöveghely:

${ }^{10}$ J. Engels: Die politische Biographie des Hypereides. München $1993^{2} .213$ skk; D. M. Lewis: Law on the Lesser Panathenaia. Hesperia 28 (1959) 239 skk.

${ }^{11}$ Vö. Horváth: i. m. (5. jegyz.) 107 skk. 


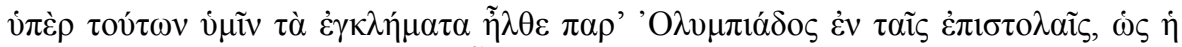

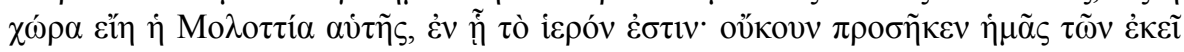

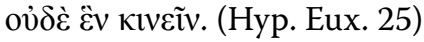

Emiatt érkeztek a szemrehányások Olympias leveleiben, hogy tudniillik Molossia, a terület, ahol a szentély áll, az övé; így nekünk annyi közünk sincs az ottani ügyekhez, hogy egy szalmaszálat keresztbe tegyünk.

Jóllehet, miként fent említettem, egyedül Oikonomidés kérdőjelezte meg expressis verbis a beszéd Comparetti-féle „ortodox” keltezését, Hammond - véleményem szerint a görög filológus álláspontját alátámasztó, helytálló megállapítást tett: Olympias önnön „statusát” (ti. „a terület, Molossia az övé”) általában molossos származása és istenfélő lelkülete szerint írta és határozta meg. Így tehát mindebből nem következik az, hogy Olympias a kijelentés, azaz a levelek megfogalmazása idején királynő vagy régens lett volna Molossiában. ${ }^{12} \mathrm{~A}$ források és a vonatkozó szakirodalmi elemzések alapján biztosat nem állíthatunk, ugyanakkor minden jel arra mutat, hogy egyfelöl a molossiai és a makedón nők, így különösen az uralkodócsaládok nőtagjainak tulajdon feletti rendelkezési joga, egyszersmind „birtokfelfogása” jelentősen különbözött az athéni gyakorlattól és szellemiségtől. (Az „enyém” / „övé” kijelentés tehát nem feltétlenül ugyanazt jelentette

${ }^{12}$ Lásd 3. jegyz. és N. G. L. Hammond: Some Passages in Arrian Concerning Alexander. CQ 30 (1980) 455-476, kül. 474: „In 330 BC, or soon after when Hyperides was defending a client, Euxenippus, he envisages Olympias as operating in Macedonia (Eux. 32, fin.), but he refers to an incident in Epirus which arose when Athens embellished the shrine of Dione at Dodona. Olympias complained in a letter which cited by Hyperides as containing these words: (...) She was explaining her status in the matter, as a Molossian by birth and no doubt as a religious woman; it does not follow that she was acting as the Molossian queen or regent [53. jegyz.: Berve, II. 287 makes her 'Herrin von Epeiros']. Although Hyperides gives few details, he treats the complaint (probably one of several) as coming officially to Athens from Olympias and Alexander

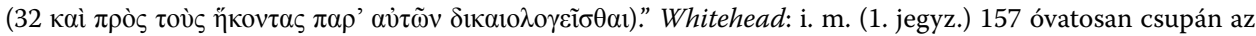
alábbiakat jegyzi meg Hammond álláspontjával kapcsolatban: „if dating implications for Eux. follow, they are to my mind uncertain”. Pedig a következmények egyértelműek: ha az állítás igaz, a beszédet nem kell szükségképpen Kr. e. 331 utánra keltezni. (Bár kétségtelen, hogy 1967-ben Hammond [N. G. L. Hammond: Epirus. Oxford 1967. 558 és 583] még úgy fogalmaz, hogy az Athénba küldött levél az ominózus sorokkal ,just before 330 B.C." született, amikor Olympias visszatért Molossiába.) Másfelől E. Carney: Olympias. Ancient Society 1987 (18) 35-62, kül. 50 skk. Hammond álláspontját megkérdőjelezve egyértelműen elfogadja, hogy az Euxenippos-beszéd Kr. e. 330 után keletkezett. 52, 29. jegyz.: „This reading is unconvincing since Olympias is telling the Athenians to keep their hands off the temple rather than telling them to go sacrifice at their own

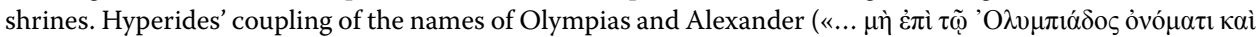

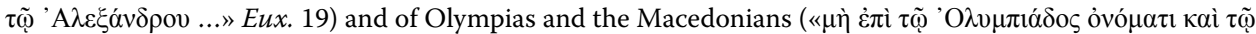
'A $A \varepsilon \xi \hat{\alpha}$ v $\delta \rho o v$... Eux. 20-21») is interesting, but does not tell us either where Olympias was or what her formal position was. Mother and son worked in concert, granted the absence of the son in the east, but without any well-defined formal arrangement. Similarly, that Hyperides imagines someone flattering both Olympias and the Macedonians tells us that he associates the two, but does not tell us the basis of the association." Carney szerint (53) Olympias biztosan a fivére halálát követően ment Molossiába. Amint megérkezett, bizonyos ideig a lányával megosztva irányított, majd fokozatosan vette át az uralmat. Hogy volt-e bármelyiküknek hivatalos címe, nem tudhatjuk. 
Molossiában és a korabeli Athénban). Másfelől Olympias és felmenői épp Dódónéhoz kötődtek leginkább.

A Hypereidés-beszéd részletét, Olympias kijelentését athéni felfogásban értelmező utókor szerint a megfogalmazás a „hivatalos” uralkodói jogkörben gyakorolt birtoklást jelenti. Ezzel szemben molossiai fogalmak szerint az utalás hovatovább a királyi család egyik tagjának magántulajdonára vagy megkülönböztetett érdekeltségére is vonatkozhatott. ${ }^{13}$ Olympias, Alexandros anyjának mértékadó kutatója, Carney is kiemeli, hogy a molossiai nők, délebbi görög társaikkal ellentétben, jelentősen nagyobb szabadságot éveztek tulajdonjogi és vallásgyakorlási szempontból egyaránt, sőt, azokat a szent körzeteket, amelyek a területükön voltak egyenesen uralni igyekeztek. ${ }^{14}$

Másfelől Olympias és családja, így apja, Neoptolemos - bár az uralkodóház minden bizonnyal nem onnan származott - különösen Kr. e. 385-től Dódónét tekinthette „sajátjának”, a molossiai uralkodói kultusz-központnak. ${ }^{15}$ Neoptolemos király dokumentumai mellett Olympias fivérének, I. Alexandrosnak is azonosították négy feliratát Dódónéban. ${ }^{16}$ Olympias molossiai azonosságtudata, ti. ő is Aiakos, Achilleus nagyapjának leszármazottja (az Aiakida-dinasztia tagja), haláláig megmaradt. Az uralkodócsalád ugyanis - így később aligha véletlenül maga Alexandros is - végső soron Achilleustól, illetve fiától, Neoptolemostól származtatta magát, aki Andromachétól nemzett fiút. Olympias különleges dódónéi kötődését bizonyíthatja az a feltételezés is, hogy első névcseréje (Polyxenából Myrtalé lett) a felnőtté válás szertartásához, Aphrodité kultuszához kapcsolódhatott. Dodónéban épp ekkoriban emeltek önálló szentélyt az istennőnek. ${ }^{17}$

${ }^{13}$ J. L. O’Neil: Olympias. „The Macedonians Will Never Let Themselves Be Ruled by a Woman”. Prudentia 31/1 (1999) 1-14, kül. 1 sk. S. B. Pomeroy: Women in Hellenistic Egypt. New York 1984. 14 skk.-ra hivatkozva kiemeli, hogy a makedón nők a vagyonukkal maguk rendelkeztek. A korábbi időszakokból egyetlen példát említ, mégpedig épp Olympias fogadalmi ajándékát Hygieiának. Az „övé” / „enyém” sajátos megfogalmazáshoz az is hozzájárulhatott, hogy Épeiros királyának, a Szicíliában elesett I. Alexandrosnak a felesége Kleopátra, Olympias lánya, Nagy Sándor nővére volt. Kleopátra férje távollétében régensként irányította Molossiát. A szerző állítása szerint mindezt vélhetően jelentősen nagyobb jogkörrel tette, mint ami anyjának, Olympiasnak Makedóniában megadatott. Lásd i. m. 11. P. Cabanes: Société et institutions dans les monarchies de Grèce septentrionale au IV siècle. REG 93 (1980) 324 skk. is amellett érvel, hogy az épeirosi nőknek a tulajdonuk birtoklása és elidegenítése terén különleges társadalmi és jogi helyzete volt. Örökölhettek és családfőként működhettek legalábbis addig, míg fiuk nagykorú nem lett.

${ }^{14}$ E. Carney: Olympias: Mother of Alexander the Great. New York - London 2006. 7 sk. Alighanem a kultuszok gyakorlásában és felügyeletében is önállóbbak voltak más görög nőkhöz képest.

${ }^{15}$ Lásd Hammond: i. m. (Epirus, 12. jegyz.) 525 skk., ahol szerző a dódónéi szent körzetben Neoptolemos által felállított Kr. e. IV. századi állami feliratokat mutat be. Lásd még Carney: i. m. (14. jegyz.) 8: „The seat of the royal family, let alone the location of its palace, is uncertain, though it seems reasonable to conclude that by Olympias' day, the Aeacids must have spent considerable time at Dodona."

${ }^{16}$ Hammond: i. m. (Epirus, 12. jegyz.) 535 skk.

${ }^{17}$ Carney: i. m. (14. jegyz.) 93 sk. inkább a dódónéi kapcsolatot és a felnőtté válás szertartását tartja valószínűnek, mint a névcserével kapcsolatos másik feltételezést, a Philipposszal történt samothrakéi eljegyzést. 
Végezetül Olympias sajátos makedóniai / molossiai statusára utalhat az a felirat is (SEG IX 2), amely azokat az államokat és személyeket sorolja fel, akik egy éhínség idején gabonát kaptak Kyrénéből. A szövegben Olympias kétszer, lánya, Kleopátra pedig egyszer szerepel. Minden más megajándékozott egytől egyig állam, de az nem derül ki, vajon az anya és a lánya milyen területet képviselve jutott az adományhoz. A puszta tény, hogy a feliraton a nevükkel szerepelnek, azt támasztja alá, hogy valamilyen értelemben állami vezetők voltak. A feliratot Kr. e. 333/332-re vagy 334/333-ra datálják. ${ }^{18}$

2. A beszéd szövegében előforduló praesens perfectum alakokat helytelen múlt idővel fordítani, mindhárom alak, a klasszikus nyelvhasználatnak megfelelően jelen állapotot tükröz, javításuk szükségtelen. ${ }^{19}$ Mindebből az következik, hogy mindhárom személy, akit Hypereidés korábban beperelt, a beszéd elhangzásakor még élt.

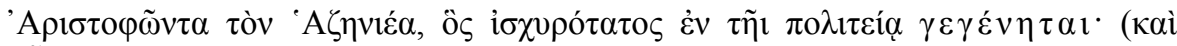

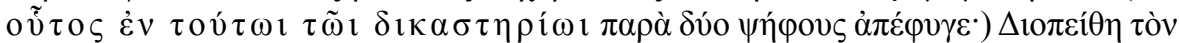

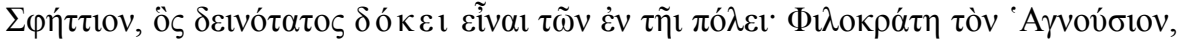

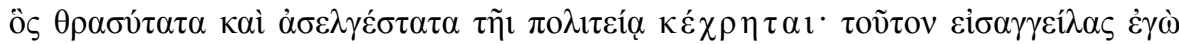

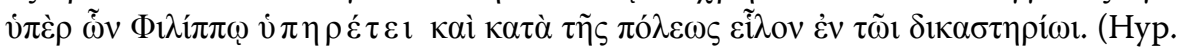
Eux. 28 sk.)

A Hadzénia démosbeli Aristophónt, a rendkívül befolyásos politikust (bizony, ő ezen törvényszék előtt két szavazatnak köszönhette a felmentését); a Sphéttos démosbeli Diopeithést, városunk félelmetes hírü polgárát; a Hagnus démosbeli Philokratést, aki a legvakmerőbb és legdurvább visszaéléseket követte el: őt én a városunk vesztére Philipposnak tett hazaáruló szolgálatai miatt törvényszék előtt ítéltettem el.

Aristophónt Hypereidés Kr. e. 362-ben vádolta be. A per pontosan keltezhető. ${ }^{20}$ Engels a Comparetti-féle elfogadott keltezés miatt a $\gamma \varepsilon \gamma \varepsilon ́ v \eta \tau \alpha$ igealakot múlt időnek igyekszik értelmezni, jóllehet erre semmilyen nyelvi kényszer nincs: „Aristophon (...) nach Dem. 18,162 und Aisch. 3,139 war (...) 330 v. Chr. verstorben. Das perfekt in Hyp. 3,28f wäre daher nicht wörtlich zu nehmen, sondern Hypereides weist hier auf die Zeit des lykurgi-

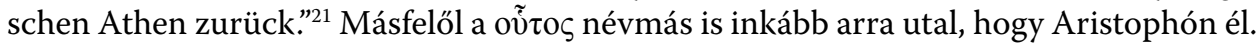

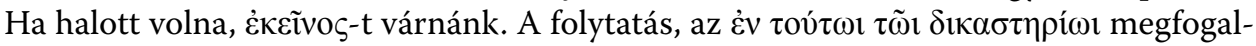
mazás nyomatékos jellege is azt sejteti, az egykori vádlott, akit Hypereidés két szavazat híján elítéltetett, él. Az Euxenippos-beszéd tehát Kr. e. 330 előtt hangzott el.

${ }^{18}$ E. Carney: Women and Monarchy in Macedonia. Norman 2000. 86. és 5. jegyz. (282).

${ }^{19}$ Hasonló, indokolatlan szövegjavítási kísérletek sora történt a Philippidés-beszéd keltezését meghatározó szöveghely esetében. Lásd L. Horváth: Eine fragwürdige Lesart: Hyp. IV. Kol. V. 8. AAHung 44 (2004) $163-170$.

${ }^{20}$ Engels: i. m. (10. jegyz.) 33.

${ }^{21}$ Engels: i. m. (10. jegyz.) 33, 39. jegyz. 
A Diopeithés elleni pert a források szűkössége miatt csak az Eubulos fémjelezte politikai körök, illetve a feliratokból ismert tevékenységei alapján lehet bizonytalanul a Kr. e. 340-es évek második felére datálni. ${ }^{22}$ A politikus befolyása a papiruszon ránk maradt megfogalmazás szerint azonban szemlátomást az Euxenippos-beszéd elhang-

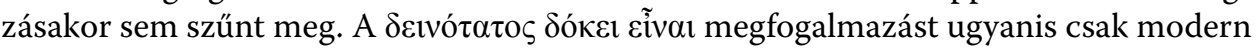

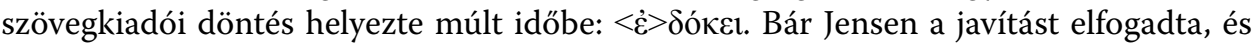
ezáltal az alakot és a múlt időt mértékadó kiindulóponttá tette a történészek számára, az igényes, belső javítások sorát is felvonultató papirusz szövegét itt sem kell megváltoztatni, miként amellett többen is kiálltak. Diopeithést tehát az Euxenippos-beszéd elhangzásakor még befolyásos szónoknak tekinthették, és ez azt jelenti, hogy időben nem járhatunk nagyon távol ismert politikai fénykorától, a 340-es évek közepétől.

A Philokratésre vonatkozó szövegrészlet esetében a megelőző két példához hasonló filológiai beavatkozási kísérletek történtek. A per, amelyben Hypereidés volt a vádló, jól datálható: Kr. e. 343-ban Philokratést távollétében halálra ítélték, majd az ítéletet később számüzetésre enyhítették. ${ }^{23} \mathrm{~A}$ papiruszon ránk maradt görög szöveg ismét

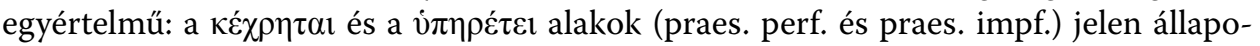
tot és jelen cselekvési folyamatot írnak le. Philokratés száműzetésében - további adataink nincsenek - folytathatta a Hypereidéstől gyalázatosként jellemzett tevékenységét

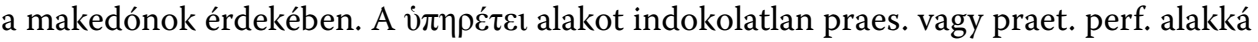

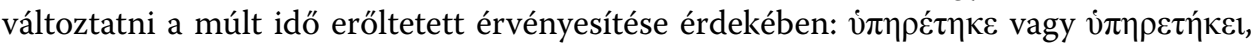
miként azt Jensennel ellentétben a kezdeményező Schneidewin, illetve Cobet nyomán több későbbi szövegkiadó is megtette. Az Euxenippos-beszéd keltezésével kapcsolatban tehát itt is arra a megállapításra juthatunk, hogy az nem lehetett időben jelentősen távol Philokratés politikai akméjától, a Kr. e. 340-es évek végétől, mert Philokratés - ha elfogadjuk a papirusz egyértelmű olvasatát - a száműzetésben is javában tovább tevékenykedhetett.

3. A beszéd keltezéséhez Hypereidés bizonyos megfogalmazásai is támpontot jelenthetnek, mert azok - véleményem szerint - „nemrégiben” történt eseményekre utalnak. Nemcsak Olympias fogadalmi felajánlása történhetett a beszéd elhangzásához képest a minap (Kr. e. 333), ${ }^{24}$ hanem Hypereidés személyes, államférfiúi példamutatása is a Makedóniából érkező parancsokkal szemben. Kr. e. 335-ben és 334-ben ugyanis a szónok felszólalt a makedón követelésekkel szemben, ezért kérhette számon az Euxenippost vádló Polyeuktoson ugyanazt a kiállást. Az Euxenippos- és Dióndas-beszéd alább idézett szöveghelyei és Ps.-Plutarchos azokat alátámasztó testimoniuma a fentieket erősíti, a Dióndas-beszéd ugyanis bizonyosan Kr. e. 334 télutóján hangzott el. ${ }^{25}$

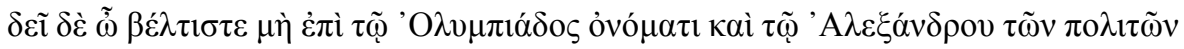

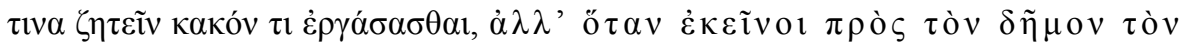

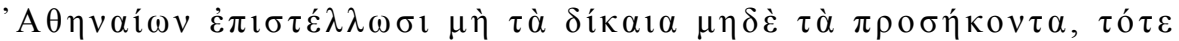

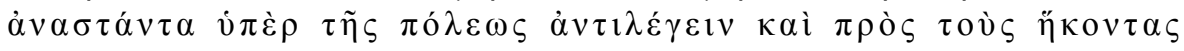

\footnotetext{
${ }^{22}$ Engels: i. m. (10. jegyz.) 371 sk.

${ }^{23}$ Whitehead: i. m. (1. jegyz.) 235 további irodalommal. Lásd még Engels: i. m. (10. jegyz.) 76 sk.

${ }^{24}$ Carney: i. m. (12. jegyz.) 51.

${ }^{25}$ Lásd Horváth L.: Az új Hypereidés. Budapest 2015. 23 skk, kül. 35.
} 


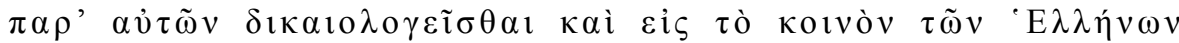

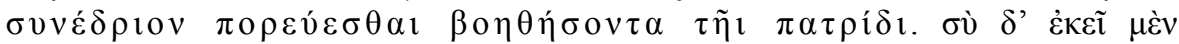

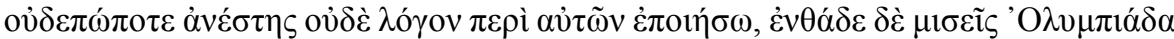

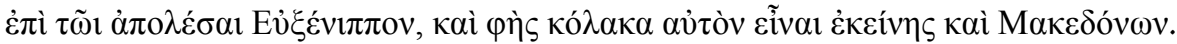
(Hyp. Eux. 19 sk.)

Ámde ne azon buzgólkodj, kiváló barátom, hogy Olympias és Alexandros nevével takarózva kárt okozz valamelyik polgártársadnak, hanem amikor ők ketten valami jogtalan és nemtelen dolgot követelnek a népgyűléstől, akkor állj fel és emeld fel szavad városunk érdekében, a tőlük érkező követekkel szemben védd igazunkat, járulj a hellének közös tanácsa elé, hogy megsegítsd hazádat! Te azonban ott soha nem álltál fel, szóba sem hoztad őket, itt viszont fenekedsz Olympias ellen, hogy Euxenippost elveszejtsd és ezért kijelented, ez az ember Olympias és a makedónok talpnyalója.

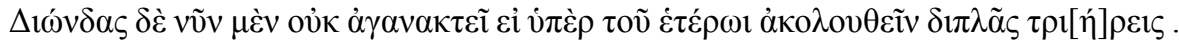

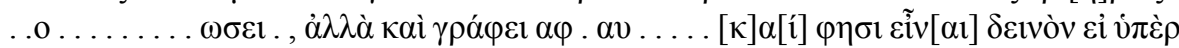

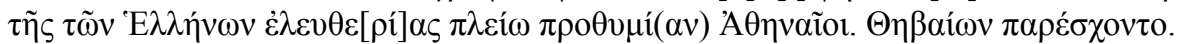

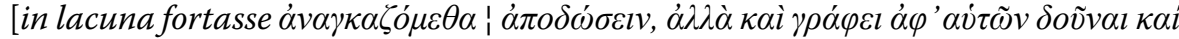
$\varphi \eta \sigma l-v e l$ simile] (Hyp. Dion. 14.)

Dióndas bezzeg most nem méltatlankodik azon, hogy holmi csatlós szerepért kétszer annyi hadihajó állítására kényszerítenek, ellenkezőleg, egyenesen azt javasolja, hogy önkéntes felajánlást tegyünk, mert - miként mondja - elképesztő, hogy a görögök szabadságáért az athéniak nagyobb odaadással voltak, mint a thébaiak.

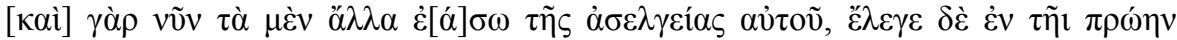

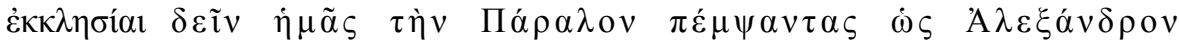

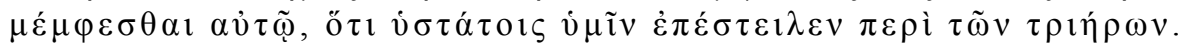
(Hyp. Dion. 24.)

A többi aljasságát most kár is említenem, a minap azonban azt javasolta a népgyülésen, hogytüstént küldjétek ki Alexandroshoz a Paralost, tegyetek panaszt nála, amiért a hajók kérdésében hozzátok fordult utolsónak.

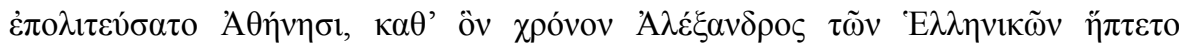

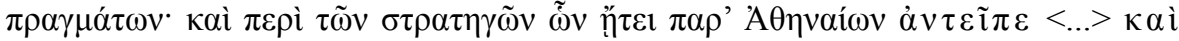
$\pi \varepsilon \rho \grave{i} \tau \tilde{\omega} v \tau \rho \imath \eta ́ \rho \omega v$. (Ps. Plut. Mor. 848E)

Az athéni közélet meghatározó alakja lett, épp az idő tájt, amikor Alexandros kezdte kiterjeszteni befolyását a hellén ügyekre. Nemcsak a hadvezérek ügyében szólalt fel ellene, amikor az athéniaktól a kiadatásukat kérte, hanem a ha dihajók esetében is. 
4. Az Euxenippos-beszédhez kötődő óróposi-kérdés, a terület rendezése, illetve újrarendezése, a szentély jövedelmének biztosítása legfeljebb egy-két évvel az Athénhoz csatolás után (Kr. e. 335) lehetett igazán időszerü. ${ }^{26}$ Egyértelműen ezt támasztja alá, hogy az Euxenippos-perben vádlóként fellépő Lykurgos elsősorban a ránk maradt feliratok szövege, másodsorban pedig a régészeti ásatások eredményei alapján Kr. e. 334 közepétől nagyszabású építkezéseket kezdeményezett Óróposban. A cél az volt, hogy Amphiaraos szentélyének és kultuszának jelentőségét Athén érdekeinek megfelelően erősítsék. Kr. e. 333-ban az Amphiareion forrását megújították, és a vízellátásáról is megfelelően gondoskodtak. A fürdés zavartalan biztosítására új vízvezetéket terveztek. Lykurgos az oltár közelében álló korábbi színházat lebontatta, és attól keletebbre új színház és oszlopcsarnok építését kezdeményezte, a templom pedig feltehetően új pronaost kapott. ${ }^{27}$ Az építkezésekkel valószínüleg egy időben az Atthis-író Phanodémos, aki másutt is a lykurgosi kultuszprogram támogatója, mondhatni ideológusa volt, ${ }^{28}$ az áldozatok bemutatását és a négyévenkénti ünnepek felújítását törvényben biztosította. Ezt a tevékenységét az athéni nép Kr.e. 332/331-ben koszorúval ismerte el:

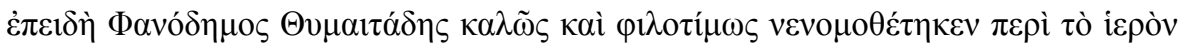

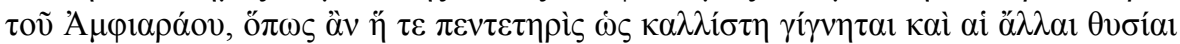

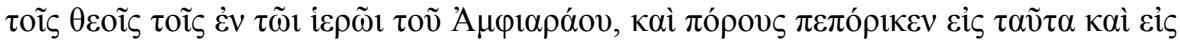

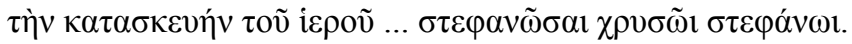

Mivel a Thymaitadai démosbeli Phanodémos szép és dicséretes törvényt terjesztett be Amphiaraos templomával kapcsolatban, egyrészt, hogy a négyévenkénti ünnep is lehetőség szerint a legfényesebb legyen, másrészt hogy a többi áldozati szertartást is nagyszerűen mutassák be az Amphiaraos-szentélyben tisztelt isteneknek, és mivel jövedelemforrást biztosított mindezekre és a templom építésére [...] aranykoszorúval tünteti ki. ${ }^{29}$

${ }^{26}$ D. Knoepfler: Oropos, Colonie d'Érétrie. Les Dossiers. Histoire et archéologie 94 (1985) 50-55, kül. 53; D. Knoepfler: Eretria xi : Décrets érétriens de proxénie et de citoyenneté. Lausanne 2001. 369-89, kül. 367 skk. meggyőzően bizonyította, hogy az irodalmi források állítása ellenére nem Philippos (Kr. e. 338), hanem Alexandros (Kr. e. 335) adta át Órópost Athénnak. Lásd a vonatkozó szakirodalom bemutatásával: Wilding: i. m. (7. jegyz.) 56, 5. jegyz.

${ }^{27}$ W. Will: Athen und Alexander. Untersuchungen zur Geschichte der Stadt von 338 bis 322 v. Chr. München 1983. 90 sk. a források hivatkozásával és további szakirodalommal.

${ }^{28}$ Horváth L.: Az athéni demokrácia műhelyéből: Hypereidés Déliakosa és a zóstéri szentély. Aetas 4 (1996) $20 \mathrm{skk}$.

${ }^{29}$ IG VII 4253. (Syll. ${ }^{3}$ 287). Vö. FGrH 325 T 3b; Will: i. m. (27. jegyz.) 91, 277. jegyz. Phanodémos kitüntetésével egy napon maga a kitüntetett is javaslatot tett Amphiaraos, a gyógyító hérósz megkoszorúzására és az arany koszorú szentélyben történő elhelyezésére, amely a ránk maradt „koszorú-feliratok” között egyedi jelenség. Az előterjesztést megőrző felirat (I. Orop. 296) annak a fohásznak is megőrizte meghatározó fordulatait, amelyet a cselekedetet végrehajtóknak a szentélyben el kellett mondaniuk. A. C. Scafuro: The Crowning of Amphiaraos. In: Greek History and Epigraphy: Essays in Honour of P. J. Rhodes. Eds. L. Rubinstein - L. Mitchell. Swansea 2009. 59 skk., kül. 76 sk. meggyőzően bizonyítja, hogy a Kr. e. 332/331-ben történt ese- 
A megújítást követő és az olympiai évekkel egybeeső négyévenkénti ünnepet ( $M e$ gala Amphiareia) első alkalommal Kr. e. 329/328-ban rendezték meg. ${ }^{30}$ Ezt igazolja az a felirat, amelyet Phanodémos kitüntetése után három évvel véstek be. Az athéni nép elismerésben részesíti azokat a népgyủlés által választott megbízottakat, akik az Amphiareionnál megrendezett versenyjátékokat kiválóan felügyelték. A sorban az első három név: Phanodémos, Lykurgos és Démadés. Will megállapítása szerint, mivel a játékokon atlétikai és lovas versenyeket is rendeztek, a küzdőtereket és a versenypályákat is bizonyosan felúították (az athéni uralom alatt, egészen Kr. e. 322-ig töretlenül virágzott a kultusz, amit számos feliratos emlék, fogadalmi ajándék bizonyít). ${ }^{31}$ Lykurgos a kisPanathénaia-ünneppel kapcsolatban egy vagy két évvel korábban (Kr. e. 336/335-ben vagy 335/334-ben) hasonló intézkedéseket foganatosított. ${ }^{32}$

mény Órópos Attikához és Athénhoz való kötődését volt hivatott erősíteni. N. Papazarkadas: Sacred and Public Land in Ancient Athens. Oxford 2011. 47 sk. az Amphiaraost elismerő egyedülálló feliratból további következtetéseket is levon. A hérószt - Phanodémos javaslatára - nem csupán koszorúval tisztelték és ajándékozták meg képletesen, hanem egyszersmind fölbirtokokat is kapott. Márpedig ebből az következik, hogy a terület kijelölése Kr. e. 335/4 és 332/1 között történt: „After all, it may not be coincidental that the decree in honour of Phanodemos was passed in the ninth prytany of 332/1. It was the ninth prytany when payments of sacred rentals were normally made and, therefore, it would have been only in the same prytany of 332/1 that the Athenians would have appreciated the effectiveness of Phanodemos' financial legislation. If so, the law and the subsequent delimitation should be dated in the preceding year, 333/2". [Kiemelés H. L.] Papazarkadas (ugyanitt 48 és 97) megerősíti a szakirodalom korábbi megállapításait, ti. az Amphiaraosnak szentelt terület Órópos mintegy 17\%-át jelenthette. Ha pedig ez így van, hozzátehetjük, hogy az többé-kevésbé valóban lefedi a phylé-párokra jutó $20 \%$-ot, azaz a területet a „bitorló” phylé-pártól vették vissza. Papazarkadas álláspontjával szemben S. D. Lambert: Inscribed Athenian Laws and Decrees in the Age of Demosthenes. Historical Essays. Leiden - Boston 2018. 195, 68. jegyz. azt sugalmazza, hogy Phanodémos saját tulajdonából tett felajánlást.

${ }^{30}$ Lásd IG VII 4254. Vö. FGrH 325 T 4. (Syll. ${ }^{3}$ 298. „Penteterida Amphiaraiorum in quartum cuiusque Olympiadis annum incidisse et anno Ol. 112, 4 [329/8] primum actam esse ex titulo n. 298 apparet" Dittenberger, 500.) Az ünnep és a versenyjátékok költségeinek fedezetét Knoepfler szerint egyértelműen az istenség számára visszaszerzett és a két athéni phylétől korábban bitorolt terület jövedelméből biztosították. Lásd $D$. Knoepfler: L'occupation d' Oropos par Athènes au IVe siècle avant J.-C.: une clérouquie dissimulée? Annuario della Scuola Archeologica di Atene e delle Missioni Italinnaane in Oriente 88 (2010) 439-454. kül. 445.

${ }^{31}$ Will: i. m. (27. jegyz.) 91.

${ }^{32}$ Lewis: i. m. (10. jegyz.) 240. Vö. R\&O ${ }^{\circ}$ 81. L. Robert: Hellenica : recueil d'épigraphie, de numismatique et d'antiquités grecques XI-XII. Paris 1960. Ch. XIII. 189-203. kül 194 skk. szerint a kis-Panathénaia-feliraton szereplő Nea terület, amelynek jövedelmeit a kis-Panathénaia-ünnep lebonyolítására fordították, nem más, mint a kevéssel korábban megszerzett nea chóra Óróposban. A merész azonosítást többen - köztük Lewis is - erősen vitatták. Magam is teljesen alaptalannak tartom. A vonatkozó szakirodalomról lásd Knoepfler: i. m. (30. jegyz.) 449, 72. jegyz. Mivel Knoepfler nehezen tudta elképzelni, hogy az Amphiaraosnak biztosított rész mellett még a kis-Panathénaia-ünnepre is elkülönítettek volna területet, még tovább ment. A Nea („plus naturelle") Órópos egészével azonosítható. Az archón név helyreállításának lehetőségeit újból megvizsgálva arra a következtetésre jut, hogy az epónymos kizárólag Euainetos lehetett: 335/334 (450). Kijelenti, hogy a feliraton említett adásbérlet épp arra a területre vonatkozik, amelyről Hypereidés beszél (452). Véleménye szerint Athén számára az óróposi feketefenyő-erdőkből kitermelhető gyanta volt a fontos bevételi forrás, a szurok ugyanis több célra is (világítás, ajtóácsolat, bor tartósítása, hadiflotta) alapanyag volt (454). Utóbbi felvetésével minden bizonnyal igaza van. 
Fentiekhez hasonlóan az Agora I 6793 jelzetű feliratot is az óróposi összefüggésben lehet értelmezni. ${ }^{33}$ Langdon a szöveget Lewis felvetése alapján vonatkoztatta az óróposi terület megosztására, Papazarkadas pedig a helynevek, feladatkörök és különösen a phylé-párra történő ritka utalás, valamint a sűrű erdővel borított területek említése miatt egyértelműen bizonyította, hogy a megörökített, területbejárást követő, amolyan földkataszteri leírás Hypereidés beszédével is összefüggésben van. ${ }^{34}$ Papazarkadas szerint Kr. e. 335 után először a phyléknek mérték ki a területet, majd azok azt magánszemélyeknek osztották tovább, az Agora I 6793 felirat pedig ezek után keletkezett. A helyreállítható nevek és személyek életrajzi adatai alapján a kiadó a feliratot a Kr. e. 330-as, 320-as évekre keltezi, további pontosítás érdekében pedig épp az Euxenippos-beszédre támaszkodik. Comparetti datálását elfogadva terminus ante quemnek Kr. e. 330-at vagy 329-et tekinti, mert úgy véli, a beszéd kevéssel a diplomáciai „levélváltás” után keletkezhetett. ${ }^{35}$ A Phanodémost elismerő felirat és a kis-Panathénaia-felirat közötti számos szövegszerű áthallás alapján pedig felveti, hogy az Euxenippos-pert kiváltó, az istennek járó jövedelmet biztosító felajánlás kezdeményezője Phanodémos volt. Véleménye szerint az athéniak a felajánlást követően osztották fel a phylék között a kevésbé termékeny területeket. Majd később a figyelmetlenség és a személyes kapzsiság vezetett oda, hogy a phylé-területek status quóját megkérdőjelezzék. ${ }^{36}$

Papazarkadas érvelésének kiindulópontja, amelyből a végeredményhez óhatatlanul kényszerpálya vezet, Comparetti keltezése, ti. az Euxenippos-beszéd legkorábban Kr. e. 330-ban keletkezhetett. Ha azonban ettől a keltezéstől elvonatkoztatunk, a történések menetét másképp - véleményem szerint - hitelesebben is vázolhatjuk. A beszédből is jól érzékelhetően jelentős államügy úgy kerülhetett igazán a kultuszteremtő

${ }^{33}$ N. Papazarkadas: The Decree of Aigeis and Aiantis (Agora I 6793) Revisited. In: ATTIKA EPIGRAPHIKA: Studies in honour of Christian Habicht. Eds. A. A. Themos - N. Papazarkadas. Athens 2009. 165-181. Lásd még Papazarkadas: i. m. (29. jegyz.) 102 skk.

${ }^{34}$ M. K. Langdon: An Attic Decree Concerning Oropos. Hesperia 56 (1987) 47-58 és Papazarkadas: i. m. (33. jegyz.) $165 \mathrm{skk}$.

${ }^{35}$ Papazarkadas: i. m. (33. jegyz.) 178 a 41. jegyzetben kifejti: kizárt, hogy az athéniak úgy küldtek volna küldöttséget Dódónéba, hogy előtte ne egyeztettek volna az uralkodóval. Csakhogy I. Alexandros időközben meghalt, és így a helyét átvevő Olympias már sérelmezhette a tevékenységet, ti. vele nem egyeztettek. Papazarkadas idézi Parkle megállapítását: H. W. Parkle: The Oracles of Zeus. Dodona-Olympia-Ammon. Oxford 1967. 142: „Evidently the consultation of the oracle which led to this Athenian dedication at Dodona had taken place recently after the death of Alexander king of the Molossi”. Másfelöl S. C. Humphreys: The Strangeness of Gods. Historical Perspectives on the Interpretation of Athenian Religion. Oxford 2004.97 („Athens had sent a theôria to make an offering in Dodona c. 331, no doubt as a discret gesture of friendship to Macedon [Hyperides IV Euxenippos 24-6]") Kr. e. 331-et veti fel a dódónéi delegáció időpontjaként, amit azonban Papazarkadas korainak tart, mert Alexandros 331/330 telén halt meg.

${ }^{36}$ Papazarkadas: i. m. (33. jegyz.) 180: „I would suggest then that Phanodemus instigated the consecration mentioned in Hyperides with the aim of raising funds - in the form of rentals, as in the case of Nea - for the celebration of the newly established Amphiaraia” és ugyanitt: „Carelessness and private greed caused problems that called for a re-examination of the satus quo of the tribal property. Hypereides' fourth speech, dating, as I believe, to 330 or thereabout, attests to such problems experienced by Akamantis and Hippothoontis. Agora I 6793 probably belongs to the same period, though I would not exclude a date later in the 320s." 
politikusok és a személyes jövedelmüket féltő phylék és magánemberek kereszttüzébe, ha az alábbi időrendet követjük: Kr. e. 335/334-ben, Órópos átcsatolását követően az athéniak (egy kisebb temenos kivételével) a teljes területet felosztották a phylék között. Kr. e. 334/333-ban a már felosztott területek közül kívánta megszerezni Lykurgos és Phanodémos a Hypereidéstől említett phylé-pár jussát az Amphiaraos-kultusz javára. Ilyen, a bevételi érdekeket mélyen sértő újrarendezést valószínűleg kizárólag isteni kinyilatkoztatással lehetett (ha egyáltalán) alátámasztani. Polyeuktosnak az Euxenippos-pert megelőző elvetélt kárpótlási javaslata is egyértelműen arra utal, hogy a már birtokban lévő phyléktől igyekeztek a területet Amphiaraosnak elvenni.

Véleményem szerint a fentiek alapján az Órópost érintő, Lykurgoshoz is köthető intézkedések, ideértve a területről származó jövedelemforrás biztosítását is (ami voltaképpen az Euxenippos-per kiindulópontja) Kr. e. 334/333-ban történhettek. Magától értetődik, hogy a törvényszéki pereskedés ezzel párhuzamosan történhetett, így mindent egybevetve Hypereidés beszédét Kr. e. 333-ra keltezhetjük.

\section{SUMMARY}

Hypereides' In Defence of Euxenippos against Polyeuktos upon His Indictment for Treason was dated 334 BCE by its first publisher Churchill Babington. Domenico Comparetti, however, soon restricted the possible date of its emergence to the period between 330 and 324 BCE. He argued that the orator could only cite the phrase „Molossia is mine” from the letter Olympias, Alexandros' mother addressed to the Athenians, if Olympias had meanwhile become the true ruler of the territory, that is, after $331 \mathrm{BCE}$, her brother's death. This dating has been taken for granted for at least a century and a half, resulting in several emendations and interpretative alternatives aligned with this notion by various editors. This paper argues that, in keeping with the traditional, easily interpretable text, the speech must be dated to 334/333 BCE, no change is necessary, Churchill Babington was right.

Keywords: Hypereides, In Defence of Euxenippos, Babington, Comparetti, dating, Olympias, Molossia

HORVÁTH LÁSZLÓ

ELTE BTK Görög Tanszék

ELTE Eötvös József Collegium

horvathl@eotvos.elte.hu

A cikk a Creative Commons Attribution 4.0 International License (https://creativecommons.org/ licenses/by/4.0) feltételei szerint publikált Open Access közlemény, melynek szellemében a cikk bármilyen médiumban szabadon felhasználható, megosztható és újraközölhető, feltéve, hogy az eredeti szerző és a közlés helye, illetve a CC License linkje és az esetlegesen végrehajtott módosítások feltüntetésre kerülnek. (SID_1) 